\title{
PENGEMBANGAN BAHAN AJAR IPA KELAS V SEKOLAH DASAR MENGGUNAKAN MULTIMEDIA INTERAKTIF BERBANTUAN ANIMASI
}

\author{
Puspa Tri Wardani ${ }^{1}$, Mijahamuddin Alwi ${ }^{2}$, Arif Rahman Hakim ${ }^{3}$ \\ ${ }^{1,2,3}$ Universitas Hamzanwadi Selong, NTB \\ Jln. Cut Nyak Dien No.85, Pancor, Selong, Lombok Timur \\ *Corresponding Author: phapuspatriwardani@gmail.com

\section{Info Artikel \\ Sejarah Artikel: Diterima: 21/09/2020 \\ Direvisi: 23/09/2020 \\ Disetujui:29/09/2020} \\ Keywords: \\ development, \\ teaching \\ science \\ interactive \\ multimedia, \\ animation

\section{Abstract} \\ This study aim in other to result teaching material used interactive multimedia based \\ animation on science subject especially on water recycled cycle in academic year 2019/2020. \\ The development learning model on this study was Borg and Gall model. This study was \\ conducted into some steps, they are (1) the need analysis step; (2) design step; (3) creating \\ and validating product step; (4) product revision step; (5) try out product step; (6) final \\ product revision step. The subject of this study was fifth grade student of MI NW No, 02 \\ Kelayu Selatan. Based on the product validation which carried out by the expert team showed \\ that the score of the sight experts was 61, on average of 4.69 with "excellent category" on the \\ material, score board $X>\overline{X_{l}}+1,80 S B i$. Whereas the score of material and language were 35 with an \\ study, \\ average of acquisition of 5 with excellent category score on the score board $X>\bar{X} \imath+1,80 S B i$. \\ The result showed, the result of field try out test was 97\% which student responded "yes", \\ while the result of study acuity was $85 \%$. Based on the result it can be concluded that the \\ teaching material which developed by the researcher was very worthy of using for science- \\ learning activities in recycled cycle materials.
}

\begin{abstract}
Abstrak
Penelitian ini bertujuan untuk menghasilkan produk berupa bahan ajar menggunakan multimedia interaktif berbantuan animasi pada mata pelajaran IPA dengan pokok bahasan siklus/daur air tahun ajaran 2018/2019. Model pengembangan pembelajaran yang digunakan dalam penelitian ini adalah Borg and Gall. Pelaksanaan penelitian terdiri dari (1) tahap analisis kebutuhan; (2) tahap desain; (3) tahap pembuatan dan validasi produk; (4) tahap revisi produk; (5) tahap uji coba lapangan; (6) tahap revisi akhir produk. Subjek penelitian adalah siswa kelas 5 MI NW No.02 Kelayu Selatan. Berdasarkan validasi produk yang dilakukan oleh tim ahli maka nilai skor dari ahli tampilan adalah 61 dengan rata-rata sebesar 4,69 dengan kategori "sangat baik" pada rentang skor $X>\bar{X} l+1,80 \mathrm{SBi}$. Sedangkan untuk materi dan bahasa adalah sama-sama 35 dengan pemerolehan rata-rata sebesar 5 dengan kategori "sangat baik" pada rentang skor $X>\overline{X_{l}}+1,80 \mathrm{SBi}$. Hasil penelitian pada siswa MI NW No.02 kelas V (lima)

menunjukkan hasil penelitian uji coba lapangan yakni; (a) Data hasil angket respon siswa menunjukkan 97\% siswa merespon ya. Sedangkan ketuntasan belajar siswa yakni menunjukkan $85 \%$. Sehingga bahan ajar yang dikembangkan oleh peneliti dinyatakan sangat layak digunakan untuk kegiatan pembelajaran IPA pada materi siklus/daur air.
\end{abstract}

\footnotetext{
"Alamat korespondensi:

Universitas Hamzanwadi Selong

Jln. Cut Nyak Dien No.85, Pancor, Selong, Lombok Timur

(C) 2020 Program Studi PGSD Universitas Flores

E-mail : phapuspatriwardani@gmail.com

Email: primagistrauniflor@gmail.com
} 


\section{PENDAHULUAN}

Pendidikan merupakan salah satu bentuk perwujudan kebudayaan manusia yang dinamis. Oleh karena itu perubahan dan perkembangan pendidikan menjadi sesuatu yang seharusnya terjadi sejalan dengan perubahan kebudayaan manusia. Perubahan dalam arti perbaikan mutu pendidikan pada semua tingkat dan perlu terus menerus dilakukan sebagai antisipasi melindungi kepentingan bangsa dimasa depan. Undang-Undang Sistem Pendidikan Nasional Nomer 20 Tahun 2003 mengemukakan bahawa pendidikan adalah usaha sadar dan terencana untuk mewujudkan potensi dirinya untuk memiliki kekuatan spiritual keagamaan, pengendalian diri, kepribadian, kecerdasan, dan akhlak mulia, serta keterampilan yang diperlukan dirinya, masyarakat, bangsa dan negara (Badan Standar Nasional Pendidikan, 2010: 5).

Sekolah merupakan sarana yang secara sengaja dirancang untuk melaksanakan pendidikan. Sekolah seharusnya menjadi pusat pendidikan untuk menyiapkan manusia menjadi individu, warga masyarakat, warga negara, dan warga dunia dimasa depan. Sekolah yang demikianlah yang diharapkan mampu melaksanakan fungsi pendidikan secara optimal, yakni mengembangkan kemampuan serta meningkatkan mutu pendidikan dan martabat manusia dalam mewujudkan masyarakat yang maju, adil, dan makmur, serta memungkinkan para warganya mengembangkan diri baik berkenanaan dengan aspek jasmaniah maupun rohaniah (Umar Tirtarahadja dan La Sulo, 2008: 172-173).

Kurikulum sebagai rencana pembelajaran adalah rencana pembelajaran disuatu sekolah. Kurikulum mencakup sejumlah mata pelajaran yang ditawarkan oleh suatu lembaga pendidikan yang harus ditempuh ataupun yang dipelajari oleh peserta didik. Sedangkan kegiatan belajar tidak termasuk kedalam kurikulum. Berbagai alternatif pengalaman belajar dapat dipilih sesuai dengan jenis kompetensi serta materi ynag dipelajari, baik di dalam kelas maupun di luar kelas. Pengalaman di dalam kelas dilaksanakan dengan interaksi antara peserta didik dan sumber belajar, seperti telaah buku, melakukan eksperimen di laboratorium IPA (Ilmu Pengetahuan Alam) atau pembelajaran berbasis teknologi dan komunikasi (Munir, 2010: 2829).

Salah satu permasalahan yang terjadi dalam dunia pendidikan adalah rendahnya mutu pendidikan pada setiap jenjang pendidikan, khususnya pendidikan dasar. Berbagai usaha telah dilakukan untuk meningkatkan mutu pendidikan nasional, antara lain melalui berbagai penelitian dan peningkatan kualitas guru, penyempurnaan kurikulum, pengadaan dan alat pengajaran, perbaikan sarana dan prasarana pendidikan dan bahakan perkembangan teknologi yang semakin maju. Kompetensi propesional yang dikembangkan materi pembelajaran diampu dan mengembangkan materi pembelajaran yang diampu secara kreatif dan memanfaatkan teknologi informasi.

Berdasarkan hasil pengamatan dan wawancara di Madrasah Ibtida'iah NW 02 Kelayu Selatan, dalam proses pembelajaran guru masih mengunakan bahan ajar cetak sebagai pengantar materi yang diampu oleh guru. Kemampuan guru dalam membuat bahan ajar berbasis teknologi muktimedia interaktif khususnya pada mata pelajaran Ilmu Pengetahuan Alam (IPA) masih kurang, sehingga dalam kegiatan pembelajan terlihat monoton atau kurang menarik, kurang memanfaatkan sarana atau fasilitas yang sudah ada seperti LCD. Dari kualitas pembelajaran yang kurang maka akan berdampak pada hasil belajar yang tidak memenuhi keriteria ketuntasan minimal (KKM).

Berdasarkan permasalahan tersebut maka guru dapat membuat bahan ajar dengan menggunakan berbagai macam media salah satunya adalah bahan ajar menggunakan multimedia interaktif dengan bantuan animasi agar siswa lebih tertarik dalam kegiatan pembelajaran khususnya dalam mata pelajaran IPA. Kegiatan pembelajaran akan lebih bermakna jika guru menyediakan bahan ajar lebih menarik. Bahan ajar yang lebih menarik akan menciptakan pengalaman belajar bagi siswa.

Bahan ajar merupakan bagian dari sumber belajar. Bahan ajar adalah segala 
bentuk bahan yang digunakan untuk membantu guru/instruktor dalam melaksanakan kegian belajar mengajar. Bahan disini bisa berupa bahan tertulis ataupun tidak tertulis (Aan Hasanah, 2012: 152).

Ilmu pengetahuan Alam merupakan terjemahan kata-kata dalam bahasa Inggris yaitu natural science, artinya ilmu pengetahuan alam (IPA). Berhubungan dengan alam atau bersanngkut paut dengan alam, science artinya ilmu pengetahuan. Jadi ilmu pengetahuan alam (IPA) atau science dapat diartikan sebagai ilmu tentang alam atau ilmu yang mempelajari peristiwa-peristiwa yang terjadi di alam semesta (Usman Samatowa, 2016: 3)

Multimedia merupakan perpaduan antara berbagai media seperti teks, gambar, grafik, audio, video, sound, dan animasi yang digunakan untuk menyampaikan pesan pada publik. Dalam bentuk sederhananya multimedia kadang diartikan sebagai persentasi konten yang menggunakan kombinasi media seperti teks, garis , gambar diam, animasi, suara dan video (Bambang, 2008: 153)

Multimedia interaktif adalah suatu multimedia yang dilengkapi dengan alat pengontrol yang dapat dioprasikan loleh pengguna, sehingga penggguna dapat memilih apa yang dikehendaki untuk proses selanjutnya. Berdasarkan pengertian tersebut maka multi media interaktif merupakan tampilan suatu tampilan multimedia yang dirancang agar tampilannya memenuhi fungsi menginformasikan dan memiliki interaktifitas kepada penggunanya (Jamal, 2011: 243).

Animasi merupakan salah satu daya tarik utama dalam mengoprasikan suatu program multimedia interaktif. Bukan saja mampu menjelaskan suatu konsep atau proses yang sukar dijelaskan dengan media lain, animasi juga memilki daya tarik estetika, sehingga tampilan yang menarik dan eyecatching (menarik mata) akan memotivasi pengguna untuk terlibat di dalam proses pembelajaran (Jamal, 2011: 250).

Berdasarkan pemaparan di atas maka peneliti melakukan penelitian tentang Pengembangan Bahan Ajar Menggunakan Multimedia Interaktif Berbantuan Animasi
Pada Mata Pelajaran IPA Pokok Bahasan Siklus Air Tahun Ajaran 2018/2019.

\section{METODE PENELITIAN}

Penelitian ini mengembangkan produk berupa bahan ajar menggunakan multimedia interaktif berbantuan animasi mata pelajaran IPA kelas 5. Model pengembangan yang digunakan dalam penelitian adalah model Borg \& Gall yang sudah disederhanakan menjadi sembilan langkah, yaitu penelitian dan pengumpulan data, desain produk, validasi desain, revisi desain, uji produk, revisi produk, uji coba pemakaian, dan revisi akhir.

\section{Potensi Masalah}

Minat siswa yang rendah selama mengikuti pembelajran sehingga mengakibatkan siswa kurang termotivasi dan kemampuan daya serap materi yang rendah. Hal ini terjadi karena tidak ada daya tarik siswa untuk mengikuti materi yang diajarkan selama perkuliahan.

\section{Pengumpulan Data}

Tahap kedua, pengumpulan data.Dilakukan pengamatan terhadap siswa yang mengikuti mata pelajaran IPA khususnya pada pembahasan siklus air atau daur air pada kelas 5 yang dimana siswa masih kurang mengoprasikan pemahaman mereka yang masih abstrak ke yang lebih konkrit. Maka peneliti melakukan pengamatan tanggapan siswa selama mengikuti pembelajaran.

Selain itu meninjau lebih lanjut mengenai penggunaan bahan ajar pembelajaran menggunakan teknologi multimedia interaktif berbantuan animasi.Apakah memungkinkan untuk diterapkan dan memiliki potensi untuk digunakan sebagai bahan ajar pembelajaran.

\section{Desain Produk}

Keberhasilan

pembelajaran menggunakan bahan ajar pembelajaran menggunakan teknologi multimedia interaktif berbantuan animasisangat bergantung pada bahan ajar yang akan disajikan.Bahan ajar yang disajikan harus yang interaktif, menarik, mencakup semua materi yang hendak diberikan, tepat sasaran tujuan pembelajaran. Implementasinya pada berbagai bidang ilmu dan pengembangan serta perkembangannya kedepannya 


\section{Validasi Desain}

Validasi desain digunakan untuk menilai bahan ajar yang dikembangkan baik dari segi materi, tampilan maupun keefektifan kerja bahan ajar yang dikembangkan.Untuk mengetahuinya dilakukan validasi perorangan maupun kelompok.Validasi perorangan dilakukan oleh ahli materi dan ahli bahan ajar.Ahli materi yang dipilih adalah 2 orang dan sekaligus sebagai ahli bahan ajar.Validasi kelompok dilakukan oleh siswa MI NW NO 02 Kelayu selatan yang mengikuti mata pelajaran IPA dengan menggunakan bahan ajar multimedia interaktif berbantuan animasi.

\section{Revisi Desain}

Revisi desain digunakan untuk melakukan revisi bahan ajar berdasarkan revisi yang diberikan ketika melakukan validasi desain.

\section{Uji Produk}

Uji produk ini meliputi uji coba kelompok terbatas hanya 10 siswa dan satu guru untuk mengukur tingkat kepraktisan dan kemenarikan bahan ajar yang dibuat.

\section{Revisi Produk}

Revisi produk didasarkan pada uji produk (kelompok terbatas).Revisi ini didapatkan dari hasil angket yang diisi oleh guru dan siswa, kemudian dicari kecenderungan pemberian sarannya.

\section{Uji Coba Pemakaian}

Setelah revisi produk selesai, maka dilakukan uji coba produk pemakaian (lapangan) terhadap guru serta siswa kelas V. Untuk mengukur tingkat kepraktisan, kemenarikan, dan keefektifan produk.

\section{Revisi Akhir}

Selanjutnya bahan ajar yang telah dikembangkan direvisi kembali guna berdasarkan saran dan masukan validator serta uji coba. Tahap ini melakukan revisi produk untuk memperbaiki hal-hal yang masih kurang baik hasilnya pada saat uji coba pemakian. Setelah uji coba lapangan tidah ada revisi pada bahan ajar.

\section{Instrumen Pengumpulan Data}

Untuk mengetahui kelayakan bahan ajar yang dikenbangkan, maka diperlukan instrumen penelitian. Instrument yang diperlukan dalam penelitian ini adalah lembar validasi, angket respon siswa, dan hasil belajar.
Lembar validasi adalah lembaranlembaran validasi yang digunakan peneliti dalam mengumpulkan data/informasi ditunjukan kepada tim ahli bertujuan untuk mengetahui apakah produk yang dihasilkan layak digunakan atau tidak. Instrument validasi tersebut berbentuk angket berupa rating scale skala 5, dengan kriteria sebagai berikut, sangat baik (5), baik (4), cukup baik (3), kurang baik (2), sangat kurang baik (1) dengan memberikan tanda check list $(\sqrt{ })$ pada masing masing kriteria yang dipilih. Adapun lembar validasi yang digunakan pada penelitian ini yaitu validasi ahli materi, ahli tampilan dan bahasa serta angket respons siswa dan lembar tes..

Validasi materi merupakan lembaran validasi ditunjukkan kepada ahli materi bertujuan untuk memberikan penilaian terhadap bahan ajar yang dihasilkan yaitu dari segi materi. Ahli materi melakukan kajian terhadap aspek-aspek ketercapaian materi dengan tujuan pembelajaran, kebenaran materi dari segi konsep dan teori, serta umpan balik soal latihan. Berdasarkan pernyataan tersebut maka dibuatlah kisi-kisi angket validasi ahli materi.

Validasi ahli tampilan memberikan penilaian, komentar dan saran terhadap produk yang telah dikembangkan dari aspek tampilan bahan ajar. Ahli tampilan melakukan penilaian dari segi tampilan bahan ajar yang dikembangkan meliputi tampilan kelengkapan identitas bahan ajar, tampilan desain bahan ajar, tampilan ilustrasi bahan ajar, dan keserasian warna pada bahan ajar yang dikembengakan.

Validasi bahasa merupakan lembar validasi ditunjukkan kepada ahli bahasa bertujuan untuk memberikan penilaian terhadap bahan ajar yang dihasilkan yaitu segi kebahasaan seperti penggunaan bahasa yang efektif, bahasa yang mudah dimengerti, dan bentuk tulisan yang mudah dipahami. Berdasarkan pernyataan tersebut maka dibuatlah kisi-kisi angket validasi ahli bahasa.

Angket merupakan sejenis pertanyaan tertulis yang digunkan untuk memperoleh informasi dari respon. Instrumen angket respon siswa digunakan untuk mendapatkan data mengenai pendapat siswa tentang bahan 
ajar yang digunakan. Bentuk instrument ini berupa angket chek list, sebuah daftar indikator pertanyaan yang nantinya responden tinggal membubuhkan tanda $(\sqrt{ })$ pada kriteria "ya" dan "tidak" dalam kolom yang sesuai.

Lembat tes digunakan untuk mengumpulkan data tentang hasil belajar siswa setelah melakukan pembelajaran menggunlan bahan ajar. Dalam menggunakan metode tes, peneliti menggunakan instrument berupa tes atau soal-soal tes.Tes yang digunakan dalam penelitian ini adalah pilihan ganda dan menjodohkan. Berdasarkan pernyataan tersebut maka dibuatlah kisi-kisi instrument hasil belajar atau tes terhadap bahan ajar yang akan dikembangkan.

\section{Teknik Analisis Data}

Data dari hasil penelitian ini dianalisis dengan menggunakan teknik analisis deskrptif kualitatif yaitu untuk data yang berupa kata-kata atau kalimat dilakukan reduksi data, pemisahan atau kelompok. Pengelompokan sehingga dapat disimpulkan, adapun data yang bersifat kuantitatif dianalisis dengan teknik presentase untuk kelayakan bahan ajar. Analisis kelayakan bahan ajar menggunakan tabel rentang skor sebagai berikut:

Tabel 1

Konversi data kualitatif dan kuntitatif dengan skala lima

\begin{tabular}{ccc}
\hline Nilai & Interval Skor & Kategori \\
\hline A & $X>\overline{X i}+1,80 S B i$ & Sangat Baik \\
B & $\bar{X} i+0,60 S B i<X \leq \bar{X} i+1,80 S B i$ & Baik \\
C & $\bar{X} i-0,60 S B i<X \leq \bar{X} i+0,60 S B i$ & Cukup \\
D & $\bar{X} i-1,80 S B i<X \leq \bar{X} \bar{x}-0,60 S B i$ & Kurang \\
E & $x<\overline{X i}-\mathbf{1}, \mathbf{8 0} S B \bar{i}$ & Sangat Kurang \\
\hline
\end{tabular}

Keterangan :

$\overline{X i}=$ Rata skor ideal $=1 / 2$ (skor maksimal

ideal + skor minimal ideal).

$S B i=$ Simpangan baku ideal $=1 / 6$ (skor

maksimal ideal - skor minimal ideal).

$\mathrm{X}=$ Skor Aktual

Untuk mencari skor rata-rata dalam memberikan penilaian terhadap produk yang dikembangakan, diguanakan rumus:

$$
\mathrm{x}=\frac{\sum \mathrm{x}}{\mathrm{N}}
$$

Keterangan:

$$
\begin{array}{ll}
\mathrm{X} & =\text { Skor rata-rata } \\
\mathrm{E} \mathrm{X} & =\text { Jumlah skor } \\
\mathrm{N} & =\text { Banyaknya butir pernyataan }
\end{array}
$$

(Nana Sudjana, 2019: 109)

\section{Analisis Lembar Validasi Tim Ahli}

Lembar validasi yang dianalisa pada penelitian ini menggunakan angket. Langkah yang digunakan dalam memberikan kualitas terhadap produk yang dikembangkan adalah berupa data skor tanggapan ahli yang diperoleh melalui lembar validasi yang diubah menjadi data interval. Pada lembar validasi disediakan lima pilihan untuk memberikan tanggapan tentang kualitas produk bahan ajar yang dikembangkan dengan memiliki jawaban range dari $1-5$. Semakin besar nilai yang diberikan maka semakin besar respon positif siswa. Apabila hasil kuisioner memberikan reaksi positif diatas $50 \%$ maka penelitian dianggap valid. Skor yang diperoleh, kemudian di konversikan menjadi data kulitatif skala lima.

\section{Analisis Angket Respon Siswa}

Analisis angket respon siswa dilakukan dengan pengamatan selama mengikuti pembelajaran. Apabila siswa yang menggunakan bahan ajar dalam pembelajaran memberikan respon lebih positif dibandingkan dengan respon siswa yang tidak menggunakan bahan ajar maka penelitian dianggap valid.Analisis respon siswa terhadap produk yang dikembangkan dapat dilakukan dengan membandingkan jumlah pemerolehan antara nilai jawaban "ya" dan "tidak" .perhitungan persentase tersebut dapat dilakukan dengan rumus berikut:

$$
P=\frac{\sum r}{\sum n} \times 100 \%
$$

Keterangan :

$\mathrm{P}=$ Jumlah \%

$\sum r=$ Jawaban Responden

$\sum n=$ Jumlah Responden

Berdasarkan perhitungan di atas maka dapat dilihat perbedaan jumlah persentase jawaban "ya" dan jawaban "tidak".Jika jawaban "ya" lebih besar daripada jawaban 
"tidak" maka produk yang diasilkan cocok digunakan.

\section{Analisis hasil belajar}

Hasil tes yang dihasilkan oleh siswa akan dianalisis sebagai persentase nilai ketuntasan belajar dengan ketuntasan klasikal. ketuntasan klasikal merupakan mengukur tingkat keberhasilan ketuntasan belajar siswa menyeluruh yang nantinya akan berdampak pada keberhasilan suatu bahan ajar yang dikembangkan. Adapun rumus yang akan digunakan untuk menghitung persentase ketuntasan belajar klasikal sebagai berikut :
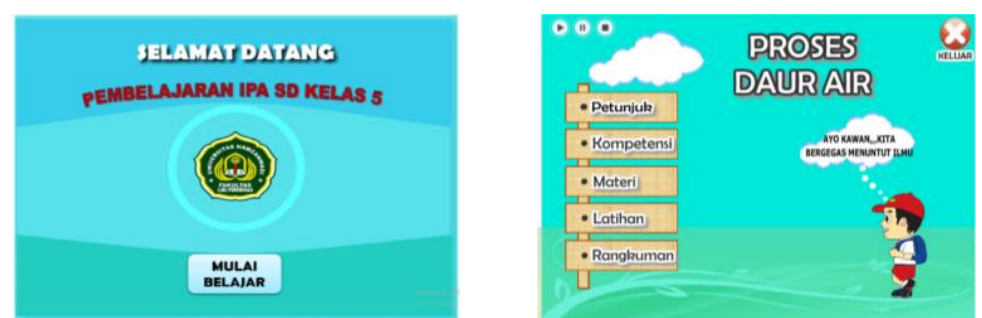

$$
P=\frac{\sum x}{N} \times 100 \%
$$

Keterangan:

$\mathrm{P}=$ Persentase ketuntasan

$\sum x=$ Jumlah siswa yang mendapat nilai $\geq 70$

$\mathrm{N}=$ Jumlah siswa yang mengikuti tes

\section{HASIL DAN PEMBAHASAN}

Uji coba lapangan dilaksanakan di MI NW No 02 Kelayu Selatan. Subjek uji coba adalah kelas V yang berjumlah 20 orang siswa. Berdasarkan hasil validasi yang dilakukan oleh ahli dapat diketahui kelayakan produk berupa bahan ajar menggunakan multimedia interaktif berbantuan animasi pada mata pelajran IPA.
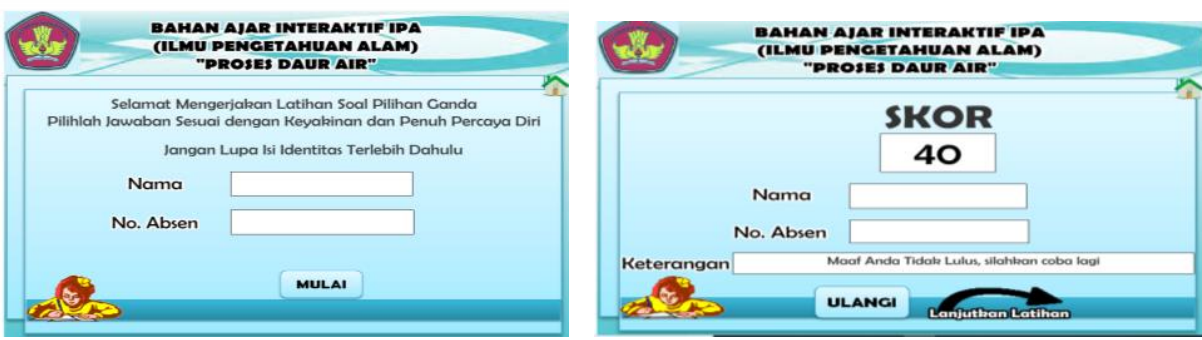

Gambar 1. Tampilan Beberapa Halaman Bahan Ajar Interaktif

Dalam kajian produk akhir dari bahan ajar menggunakan multimedia interaktif ahli tampilan. Nilai yang diperoleh dari berbantuan animasi maka diperoleh produk rata 4,69 dengan kategori sangat baik atau akhir. Hasil kajian produk akhir tersebut antara layak berada rentang skor $X>\overline{X_{l}}+1,80 \mathrm{SBi}$. lain :

Tabel 2

Hasil Validasi Ahli Tampilan

\begin{tabular}{|c|c|c|}
\hline No & Aspek Yang Dinilai & Nilai \\
\hline I & $\begin{array}{l}\text { Bahan Ajar } \\
\text { Menggunakan } \\
\text { Multimedia Interaktif } \\
\text { Berbantuan Animasi }\end{array}$ & 61 \\
\hline \multicolumn{2}{|c|}{ Skor Total } & 61 \\
\hline \multicolumn{2}{|c|}{ Rata-rata } & 4,69 \\
\hline \multirow{2}{*}{\multicolumn{2}{|c|}{$\begin{array}{l}\text { Kategori } \\
\text { Rentang Skor }\end{array}$}} & Sangat Baik \\
\hline & & $X>\overline{X_{l}}+1,80 S B i$ \\
\hline
\end{tabular}

Kelayakan bahan ajar menggunkan
Serta dikatakan layak juga berdasarkan revisi sesuai dengan saran validator.

Tabel 3

Hasil Validasi Ahli Materi Dan Bahasa

\begin{tabular}{clc} 
No & \multicolumn{1}{c}{ Aspek Yang Dinilai } & Nilai \\
\hline I & $\begin{array}{l}\text { Bahan } \\
\text { Menggunakan } \\
\text { Multimedia } \\
\text { Berbantuan Animasi }\end{array}$ & 35 \\
& Anteraktif & \\
\hline Skor Total & 35 \\
\hline Rata-rata & 5 \\
\hline Kategori & Sangat Baik \\
\hline Rentang Skor & $X>\overline{X \imath}+1,80 \mathrm{SBi}$
\end{tabular}

multimedia interaktif berbantuan animasi dari 
Kelayakan bahan ajar menggunkan multimedia interaktif berbantuan animasi dari ahli materi dan bahasa. Nilai yang diperoleh dari tanggapan ahli setelah divalidasi adalah rata-rata 5 dengan kategori sangat baik atau layak berada rentang skor $X>\overline{X_{l}}+1,80$ SBi.

Serta dikatakan layak berdasarkan revisi sesuai dengan saran validator.

\section{Respon siswa}

Dari hasil observasi pembelajaran berlangsunng selama 2 kali pertemuan diperoleh respon siswa lebih banyak merespon "ya" dibandingkan dengan respon "tidak" dibuktikan dengan perbandingan dengan data hasil angket respon siswa menunjukkan 97\% siswa merespon ya dan $3 \%$ menjukkan respon tidak.

\section{Hasil Belajar}

Berdasarkan penyelesaian soal yang dilakukan siswa maka diperoleh hasil belajar dengan rata-rata nilai sebanyak 85,25 dan bahan ajar yang dikembangkan dikatakan layak karena $85 \%$ siswa dapat menjawab dengan baik.

Bahan ajar dengan menggunakan multimedia interaktif berbantuan animasi telah divalidasi oleh ahli media dan ahli materi pembelajaran. Berdasarkan hasil validasi dari ahli tampilan mendapat rata-rata sebesar 4,69 yang termasuk ke dalam kriteria "Sangat Baik" dengan prosentase kelayakan sebesar $93,8 \%$ berada pada rentang skor $X>\overline{X l}+1,80$

SBi. Sedangkan hasil validasi dari ahli materi dan bahasa mendapat rata-rata sebesar 5 yang termasuk ke dalam kriteria "Sangat Baik" dengan prosentase kelayakan sebesar $100 \%$ berada pada rentang skor $X>\overline{X_{l}}+1,80 \mathrm{SBi}$.

Berdasarkan hasil validasi dari ahli media dan materi pembelajaran, bahwa bahan ajar berbasis komputer sudah layak digunakan meskipun ada sedikit revisi, komentar dan saran dari dosen pembimbing, ahli media dan ahli materi pembelajaran.

Bahan ajar menggunakan multimedia interaktif berbantuan animasi merupakan salah satu bahan ajar yang memanfaatkan penggunaan perangkat multimedia shoftwere sebagai sarana yang akan digunakan untuk mengajar. Bahan ajar ini memiliki komponen menu yaitu menu utama, submenu seperti petunjuk tombol, SK dan KD, materi, latihan dan rangkuman. Adapun yang disediakan dalam bahan ajar ini agar materi lebih menarik dan dimengerti yaitu menyediakan berbagai contoh gambar yang sesuai dengan materi serta menyediakan vidio animasi sebagai salah satu sarana pendukung agar materi dapat terealisasikan lebih baik sehingga peserta didik mampu memahami materi lebih baik pula.

Pendesainan bahan ajar ini meliputi gambar-gambar yang sesuiai dengan materi seperti contoh gambar siklus/daur air, gambar jenis-jenis siklus/daur air, gambar kegiatan yang mempengaruhi siklus/daur air. Selaian menyediakan gambar bahan ajar ini juga menyediakan vidio animasi berupa proses terjadinya siklus/daur air tersebut. Bahan ajar ini menyediakan dua bentuk vidio animasi diantaranya vidio yang berisi tentang proses siklus/daur air secara umum dan vidio proses siklus/daur air secara rinci.

Bahan ajar ini didesain dengan bentuk dan warna tulisan yang mudah di baca oleh peserta didik. Penyediaan latar yang menarik agar peserta didik tidak mudah bosan. Bahan ajar ini juga menyediakan musik berbentuk lagu anak agar siswa bisa termotivasi dalam belajar.

Bahan ajar ini menyediakan bentuk latihan yang inovatif seperti latihan menjodohkan. Peserta didik dapat menjodohkan soal dengan jawaban yang tersedia dalam bahan ajar dengan memilih salah satu dari tujuh jawabann yang tersedia. Dalam bahan ajar ini terdapat pula kriteria ketuntasan nilai agar peserta didik mampu mengulang apabila tidak memenuhi kriteria ketuntasan nilai/KKM.

\section{SIMPULAN DAN SARAN}

Kesimpulan yang dapat diambil dari pengembangan bangan bahan ajar menggunakan multimedia interaktif berbantuan animasi ini adalah setelah di adakannya penelitian guna menguji bahan ajar interaktif yang telah dikembangkan. Materi bahan ajar interaktif yang telah di kembangkan layak untuk siswa jenjang SD. Hal ini karena penilaian dari validator dan nilai hasil belajar siswa dan angket respon siswa menunjukkan 
tanggapan lebih banyak respon ya dari pada respon tidak. Dengan produk bahan ajar interaktif yang telah dikembangkan, di harapkan siswa dapat lebih memahami materi dengan baik dan aktif dalam pembelajaran.

Bahan ajar menggunakan multimedia interaktif dimanfaatkan oleh peserta didik sebagai refrensi pembelajaran agar lebih cepat mengerti tentang materi proses terjadinya siklus/daur air. Sedangakan manfaatnya untuk guru yaitu sebagai acuan untuk menciptakan pembelajaran yang lebih bervariasi bagi peserta didik sehingga peserta didik tidak mudah bosan.

\section{DAFTAR PUSTAKA}

Aan Hasanah. (2012). Pengembangan Propesi Guru. Bandung: Pustaka Setia.

Badan Standar Nasional Pendidikan.(2010). Paradigma Pendidikan Nasional Abad XXI. Jakarta: BSNP

Bambang Adrimyanto. (2010). Pembuatan Animasi Dengan Macromedia Flash 8.Jakarta: Kementrian Pendidikan Nasional.

Jamal MA. (2011). Tips Efektif Pemanfaatan Teknologi Informasi Dan Komunikasi Dalam Dunia Pendidikan. Yogyakata: Diva Press.

Munir. (2010).Kurikulum Berbasis Teknologi Informasi dan Komunikasi. Bandung: Alfabeta

Umar Tirtahanrdja dan La Sulo.(2008). Pengantar Pendidikan. Jakarta: Rineka Cipta

Usman Samatowa. (2016). Pembelajaran IPA Di Sekolah Dasar. Jakarta Barat: Indeks. 